Canadian University Music Review

Canadian University Music Review

Revue de musique des universités canadiennes

\title{
Mrs. J.B. Carmichael and the Edmonton Civic Opera Society, 1935-1971
}

\section{Wesley Berg et Gerry Paulson}

Volume 17, numéro 2, 1997

URI : https://id.erudit.org/iderudit/1014785ar

DOI : https://doi.org/10.7202/1014785ar

Aller au sommaire du numéro

\section{Éditeur(s)}

Canadian University Music Society / Société de musique des universités canadiennes

\section{ISSN}

0710-0353 (imprimé)

2291-2436 (numérique)

Découvrir la revue

\section{Citer cet article}

Berg, W. \& Paulson, G. (1997). Mrs. J.B. Carmichael and the Edmonton Civic Opera Society, 1935-1971. Canadian University Music Review / Revue de musique des universités canadiennes, 17(2), 30-48. https://doi.org/10.7202/1014785ar

\section{Résumé de l'article}

Born in Indiana and trained as a singer, violinist, and conductor in Chicago and New York, Beatrice van Loon travelled to Edmonton, Alberta, in the fall of 1920 as the leader of an all-female ensemble. She married a local dentist and as Mrs. J.B. Carmichael played in the Edmonton Symphony Orchestra and conducted an orchestra at the University of Alberta until 1934. She founded the Edmonton Civic Opera Society in 1935 and worked as its artistic director until her death in 1964. For more than four decades she gave unstintingly of herself to audiences and music students in her adopted city.
All Rights Reserved @ Canadian University Music Society / Société de musique des universités canadiennes, 1997
Ce document est protégé par la loi sur le droit d'auteur. L'utilisation des services d'Érudit (y compris la reproduction) est assujettie à sa politique d'utilisation que vous pouvez consulter en ligne.

https://apropos.erudit.org/fr/usagers/politique-dutilisation/ 


\title{
MRS. J.B. CARMICHAEL AND THE EDMONTON CIVIC OPERA SOCIETY, 1935-1971
}

\author{
Wesley Berg and Gerry Paulson
}

In the fall of 1920, a young woman from Chicago arrived at the MacDonald Hotel in Edmonton, Alberta as the leader of a musical ensemble. After marrying a local dentist, this energetic professional musician stayed on in Edmonton and became a central figure in the musical life of the city at a time when women were struggling to find recognition and equality in the musical profession on the North American continent.

The participation of women in professional music organizations in the late nineteenth and early twentieth centuries has been the subject of considerable interest in the past few years. ${ }^{1}$ Women were excluded from playing in professional orchestras in the United States until well into the twentieth century. Conservatories were turning out more and more female musicians, however, and one result was the formation of orchestras consisting of only women. ${ }^{2} \mathrm{By}$ 1908 there were some thirty female orchestras in the United States. ${ }^{3}$ If opportunities for female orchestral musicians were scarce in the early years of the twentieth century, opportunities for female conductors were even scarcer. ${ }^{4}$

1 Christine Ammer, Unsung: A History of Women in American Music (Westport, Conn.: Greenwood Press, 1980); Jane Weiner Lepage, Women Composers, Conductors, and Musicians of the Twentieth Century: Selected Biographies (Metuchen, N.J.: The Scarecrow Press, 1980); Carol NeulsBates, Women in Music: An Anthology of Source Readings from the Middle Ages to the Present (New York: Harper and Row, 1982); Jane Bowers and Judith Tick, eds., Women Making Music: The Western Art Tradition, 1150-1950 (Urbana and Chicago: University of Illinois Press, 1986). For information on the most recent discussions of this topic in Canada, see Edward Kovarik's conference report on "With a Song in Her Heart: A Celebration of Canadian Women Composers through Performance and Discussion," Canadian University Music Review, no. 15 (1995): 154-56.

2 See especially the fifth chapter of Ammer, Unsung, "Apartheid: The All-Women's Orchestras," 99-115. The first experience audiences in the United States had with such a group was the Vienna Ladies Orchestra that arrived in North America in 1871. The most prominent and long-lived professional ensemble in North America was the Fadette Women's Orchestra of Boston, founded in 1888 by violinist Caroline B. Nichols. It survived until 1920, presented more than 6,000 concerts in the United States and Canada, and gave professional orchestral experience to more than 600 women (p. 105).

3Karin Pendle, ed., Women and Music: A History (Bloomington and Indianapolis: Indiana University Press, 1991), 156. See also Carol Neuls-Bates, "Women's Orchestras in the United States, 1925-45," in Bowers and Tick, Women Making Music, 349-69.

4One of first American female conductors to achieve national prominence was Antonia Brico, a graduate of the University of California at Berkeley and the master school of conducting at the State Academy of Music in Berlin, who made her debut with the Berlin Philharmonic in 1930. Like other female conductors, however, Brico was forced to conduct women's orchestras if she wanted to work regularly. Ammer, Unsung, 112. 
It is against this background that we can begin to understand the arrival and subsequent work in Edmonton of Beatrice van Loon, a product of the musical subculture to which we have just referred. In addition to telling the story of a musical organization whose activities played an important role in the preservation and development of operatic music in the 1930s and 1940s in Edmonton, a study of her work and the impact she had on musical life in Edmonton can provide some insights into the qualities of the female musicians who began to break down the gender barriers surrounding North American musical establishments in the first half of the twentieth century. ${ }^{5}$ Such a study can also demonstrate the dramatic impact one person can have on the musical life of a relatively large community and can lead to some thoughts on the value and meaning of amateur music-making in a community.

Beatrice van Loon was one of five daughters born to Mr. and Mrs. Henry van Loon of South Bend, Indiana in 1889.6 Her mother was of Scottish descent, her father Dutch. Her father was a professional musician, and she showed signs that she might follow in his footsteps as early as the age of four, when she sang in a concert in Aberdeen, North Dakota, where the family had taken up residence. She continued to appear in public after this early debut, and shortly after her tenth birthday began to study the violin and take harmony lessons.

Around this time her family moved to Chicago, where she studied violin with Frederick Kellogg, a Chicago musician who specialized in working with children. ${ }^{7}$ From Kellogg, whom she continued to visit from time to time, she began to receive instruction in conducting. Her first substantial conducting engagement occurred at the age of 16 , when she conducted an operetta that included 100 children in the cast and 50 players in the orchestra.

At the age of seventeen she entered and won a vocal competition, a competition, according to John Oliver, in which she was the only female. Following this event she began vocal studies, first with Gertrude Gosscup Perkins and then with Carl Felker, who had been a singer and coach in Berlin. After four years of study, Felker suggested that she continue her studies in Germany, but the beginning of World War I just before she was to set sail forced her to change her plans. She continued her training in Chicago, and began to make professional appearances as a vocalist. She subsequently embarked on a five-year association as vocal soloist with a touring band based in New York and conducted by Frederick Neil Innes, who also gave her instruction in conducting. ${ }^{8}$

5Gerry Paulson, "History of the Edmonton Civic Opera Society, 1935-1971," unpublished research paper (University of Alberta, 1993), 3-5. We are indebted to Mr. John Peets for the use of his archival materials, collected during his years as a violinist and unofficial historian and photographer with the Edmonton Civic Opera Society.

6Unless otherwise indicated, biographical information about Mrs. J.B. Carmichael is drawn from a biography prepared for the tenth anniversary of the Edmonton Civic Opera Society by John Oliver, music critic for the Edmonton Bulletin. J.B. Carmichael collection, City of Edmonton Archives. We are grateful to John Peets for supplying us with a copy.

7 According to Oliver's account, she then began instruction with Oswald Krause, supposedly a member of the first violin section of the Chicago Symphony Orchestra, who included orchestral repertoire in her lessons. The Director of the Chicago Symphony Orchestra Archives is unable to verify the presence of someone called Oswald Krause in the orchestra at that time. Our thanks to Brenda Nelson-Strauss for this information.

8Frederick Neil Innes is the only one of Mrs. Carmichael's teachers who appears in standard 
At the conclusion of her stint with the Innes band, van Loon returned to Chicago, where she finished her studies for a Bachelor of Music degree and took on Loro Gooch as a manager. Gooch decided to form an all-girl orchestra, dressed in traditional Dutch costumes. Billed as Beatrice van Loon's Holland Girls Orchestra, the ensemble consisted of seven instrumentalists who were paid $\$ 312.50$ per week as they toured the United States. ${ }^{9}$ Although the group met with success, van Loon's association with the group came to an end when she became ill with influenza in New York and was forced to withdraw from the ensemble in order to recover.

Upon her return to Chicago, Gooch asked her to organize a similar group to travel to Edmonton, Alberta, where David Mulligan, head of the Canadian National Railway hotel system, was looking for an ensemble to perform for an eight-week engagement at the MacDonald Hotel in the fall of 1920. Mulligan persuaded van Loon to come to Edmonton, even though she had originally not wanted to travel with the group.

The orchestra was a success and Beatrice van Loon was the star attraction, conducting, playing violin, and singing ballads or arias from light or grand opera. Dr. J.B. Carmichael, an Edmonton dentist and frequent visitor to the MacDonald Hotel, noticed her, courted her, and married her on 3 November 1920 , and from that time on van Loon became a vital and significant part of musical life in Edmonton. Henceforth her professional name was Mrs. J.B. Carmichael, although her students and colleagues knew her affectionately as Auntie Van.

Her musical energies in her first fifteen years in Edmonton were divided between the Edmonton Symphony Orchestra, the University of Alberta, and the Edmonton Women's Musical Club. Shortly after her marriage, Carmichael became a member of the Edmonton Symphony Orchestra, an organization that had begun regular concerts in the fall of 1920 . For the first half of her thirteen years in the orchestra she was the only regular female member in an ensemble that normally had twenty-four to twenty-seven members in the string section, with a total membership of forty-five to forty-seven musicians. On 2 November 1929 the Edmonton Bulletin ran an article dedicated to her accomplishments precisely because she was the only female member of the orchestra. Her response was, "If I'd worn evening dress like that of the other musicians you'd never have noticed me." 10 The writer of the article also noted her accomplishments as one of the city's best conductors, citing her work at the University of Alberta.

biographical reference works. Innes was a trombone virtuoso born in London in 1854 . He led the Innes Band of New York on tours of the country from 1887 to 1915, established the Innes School of Music (which offered home study courses for bandmasters, orchestra directors and instrumentalists) in 1916, and in 1923 moved to Chicago, where he became president of the Conn National School of Music in 1923 and where he died in 1926. Raoul Camus, "Innes, Frederick Neil," The New Grove Dictionary of American Music, 2:479-80. In 1925 Carmichael returned to Chicago to do a radio broadcast with the Innes band on Westinghouse KYW. In 1926 and 1927 she travelled to Grand Forks, North Dakota to perform with the University of North Dakota Concert Band. Newspaper clippings in Mrs. J.B. Carmichael Collection, City of Edmonton Archives.

9 Information from L. Gooch and Independent Chatauqua Association, Bloomington, Illinois, J.B. Carmichael Collection, Edmonton City Archives. 
Although most sources suggest that the ESO ceased to exist in 1932, research into Carmichael's career has revealed an interesting epilogue to the story. ${ }^{11}$ In March 1933, after serving as assistant conductor to Frederick Holden-Rushworth, she was appointed conductor of the Edmonton Symphony Orchestra when Holden-Rushworth left Edmonton. ${ }^{12}$ The orchestra had been rehearsing all season but had not given a concert. In the third week of March 1933 she led the group of musicians in the first and, apparently, only concert of the season. The reviewer had this to say: "Rarely has the group given a performance with such zest, worked in such absolute sympathy with its conductor, or shown such fine all round musicianship."

It was the impression of the music critic that Mrs. Carmichael was the only woman in the Dominion to have held such a position. Clearly, the fact that the group was able to manage only one concert in the 1932-33 season was an indication that the ESO was in trouble - it was, after all, the depths of the Great Depression - but its last concert did give a female conductor an opportunity that scrutiny of the available sources suggests was a first for Canada and not very common elsewhere. ${ }^{13}$ The reviewer took note of the occasion with interest and pride; Carmichael's ascent to the podium, heretofore reserved for male musicians only, was apparently not a problem. One might argue that musical developments on the frontier in the Canadian West were governed by pragmatism and infused with a kind of grass roots democratic ethos that made the acceptance of this kind of appointment not only possible but uncontroversial. 14

During the 1920 s and early 1930 s Mrs. Carmichael had also been very active at the University of Alberta. She began working with an orchestra at the

10Edmonton Bulletin, 2 November 1929. Mrs. Carmichael was indeed the only woman listed in the program for the opening concert of the 1929-30 season on 20 October 1929. Subsequent programs for that season show that the second violin section was augmented by someone called Leona Huffman. Mrs. Carmichael seems to have been the only woman to play regularly in the orchestra from 1920 until the eighth season in 1927-28, when she was joined by two women listed as Miss Gladys Flint in the first violin section and Miss C. Gagner in the cello section. From that time onward there was usually at least one other woman in the orchestra, although Mrs. Carmichael was the only female to be a member throughout the entire thirteen years of the orchestra's first incarnation. It should be noted that on occasion, as in January 1925, she stepped out of the ranks of the violin section to sing an aria with the orchestra.

11 Encyclopedia of Music in Canada, 2nd ed., s.v., "Edmonton Symphony Orchestra" (hereafter cited as EMC). See also ESO "Encore," September 1981.

12Edmonton Bulletin, 22 March 1933. The ESO was revived in 1952, since when it has continued until the present day.

13In "Edmonton Symphony Orchestra," EMC, the name of the very first conductor of the Edmonton Symphony Orchestra is given as Alberta Weaver Winston, suggesting that this person may have been a female. According to the announcements in the Edmonton Bulletin leading up to the November debut of the orchestra, the musical director was Albert Weaver-Winston. See, for example, the music page, Saturday 13 November 1920 . One other instance of a woman conducting an orchestra in Canada has been brought to my attentions: Eva Rose York formed a Philharmonic Society in Belleville, Ontario, and conducted her Meditation for orchestra at a concert given 30 May 1887.

14See Wesley Berg, "Music in Edmonton 1880-1905," Canadian University Music Review, no. 7 (1986): 161-63; and Wesley Berg and Jonathan Bayley, "W.J. Hendra: A Pioneer Musician in Edmonton," Alberta History 38 (1990): 2-3, for other examples of how Edmonton musicians responded to problems created by isolation or a lack of resources. 
University in $1923 .{ }^{15}$ By 1925 the group consisted of some thirty-seven players who performed at various University functions throughout the year. A smaller ensemble from within this orchestra was organized to give regular live broadcasts on CKUA radio, a radio station established by the University of Alberta in 1927. In 1926 the University Concert Orchestra and the University Glee Club, the latter under the leadership of Professor L.H. Nichols, a physics professor and unofficial university organist, combined to produce a series of light operas: Maritana in 1927, The Crimson Star in 1929, The Lucky Jade in 1930, and The Bohemian Girl in 1931.16

In 1946 Carmichael explained her interest in musical theatre in this way: "I feel that the voice and violin go together even more suitably than the voice and piano. My environment was always inclined more to opera than purely orchestral work and maybe that is why I prefer it." 17 In 1932 the orchestra and glee club combined to form the University Philharmonic Society and in 1934 produced Joan of the Nancy Lee. ${ }^{18}$ According to Enid Brooks née Legate, a student in the Faculty of Arts from 1931 to 1934 and a violinist in the University Orchestra under Mrs. Carmichael, Carmichael had a way of making rehearsals enjoyable while maintaining strict discipline. Mrs. Brooks's most vivid memories of her are that she made a point of getting to know all the students and that she always had an air of complete competence. ${ }^{19}$

Carmichael discontinued her work with the University in 1934, perhaps because she had begun working on more substantial projects several years earlier. The financial crisis of October 1929 and the ensuing Great Depression brought many musical organizations to their knees. One group that managed to survive was the Edmonton Women's Musical Club, an organization that relied on volunteers for most of its activities and was therefore not so vulnerable to economic fluctuations. It was the Women's Musical Club that began the chain of events that led to the formation of the Civic Opera Society. The Edmonton Women's Musical Club, like similar organizations in many Canadian cities, sponsored touring artists, organized lectures, and promoted local talent through scholarships and competitions. ${ }^{20}$ In 1932 the Women's Musical Club, which sponsored a chorus as one of its activities, asked Carmichael to conduct a concert version of a grand opera it wished to produce. Gounod's Faust, with orchestral accompaniment, was presented in McDougall Church. ${ }^{21}$ This was followed by concert versions of Cavalleria rusticana and Carmen presented on the stage of the Empire Theatre in the next two years. ${ }^{22}$

15 Andrew Zinck, "A History of Music-Making at the University of Alberta: The First Fifty Years" (unpublished research paper, 1988), 12.

16Maritana (1845) was an opera by Wallace; The Bohemian Girl (1843) by Balfe. The Lucky Jade by J.B. Harrison and Don Wilson, and The Crimson Star, by Estelle and Palmer Clark, are obscure works not listed in standard lists of operettas.

17 John Oliver, 10th Anniversary Program, 1946.

18 Evergreen and Gold, University of Alberta Student Union Yearbook (1932-33): 158.

19 Interview with Enid Brooks, 1 October 1994.

$20 E M C$, 2nd ed., s.v. "Women's Musical Clubs."

21 10th Anniversary Program.

22 Edmonton Bulletin, 24 February 1933. 


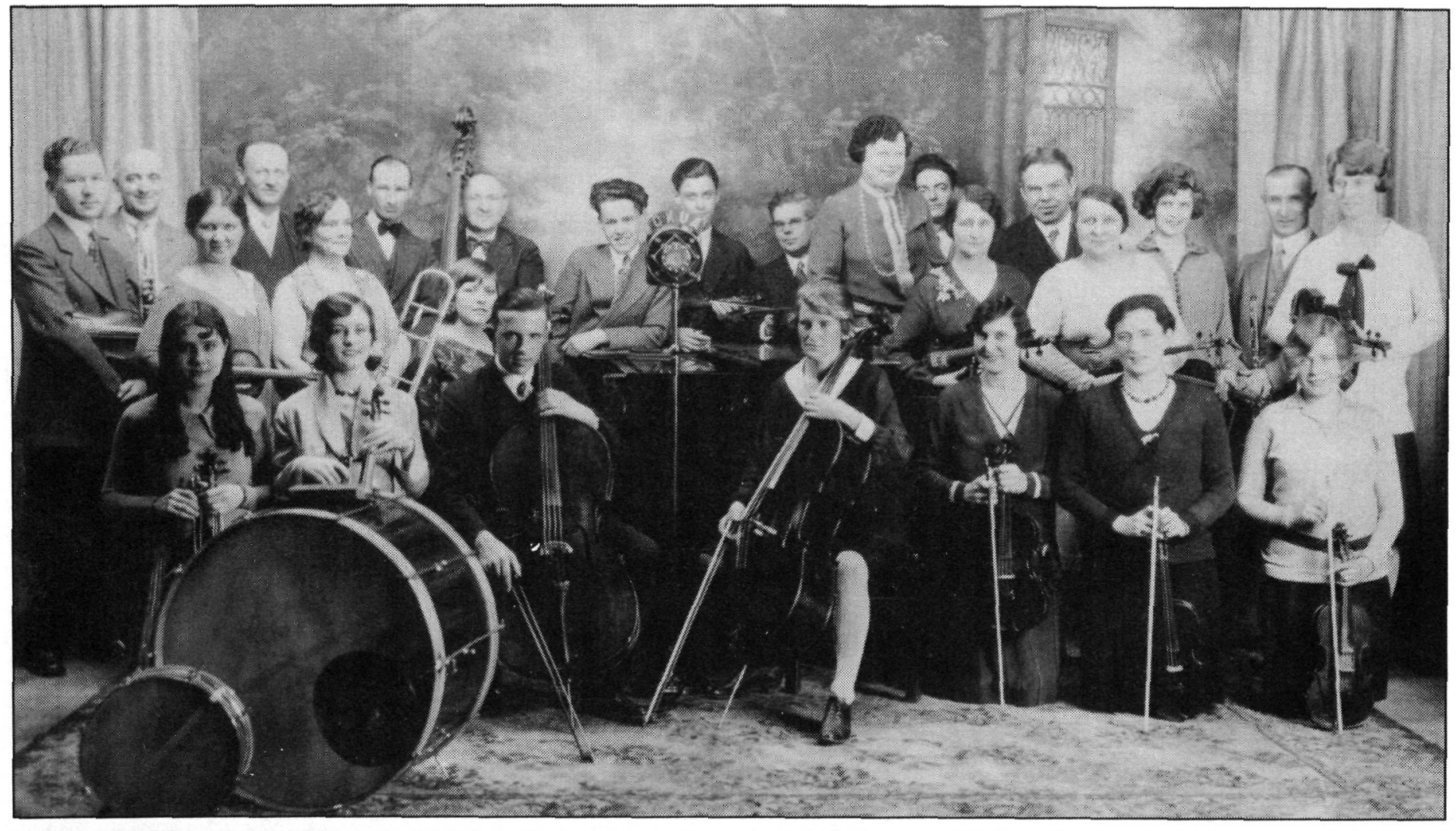

Plate 1: The CKUA Radio Orchestra in 1927. John Peets, whose archives are the main source of information for a later stage of Carmichael's career, can be seen at the far left. 


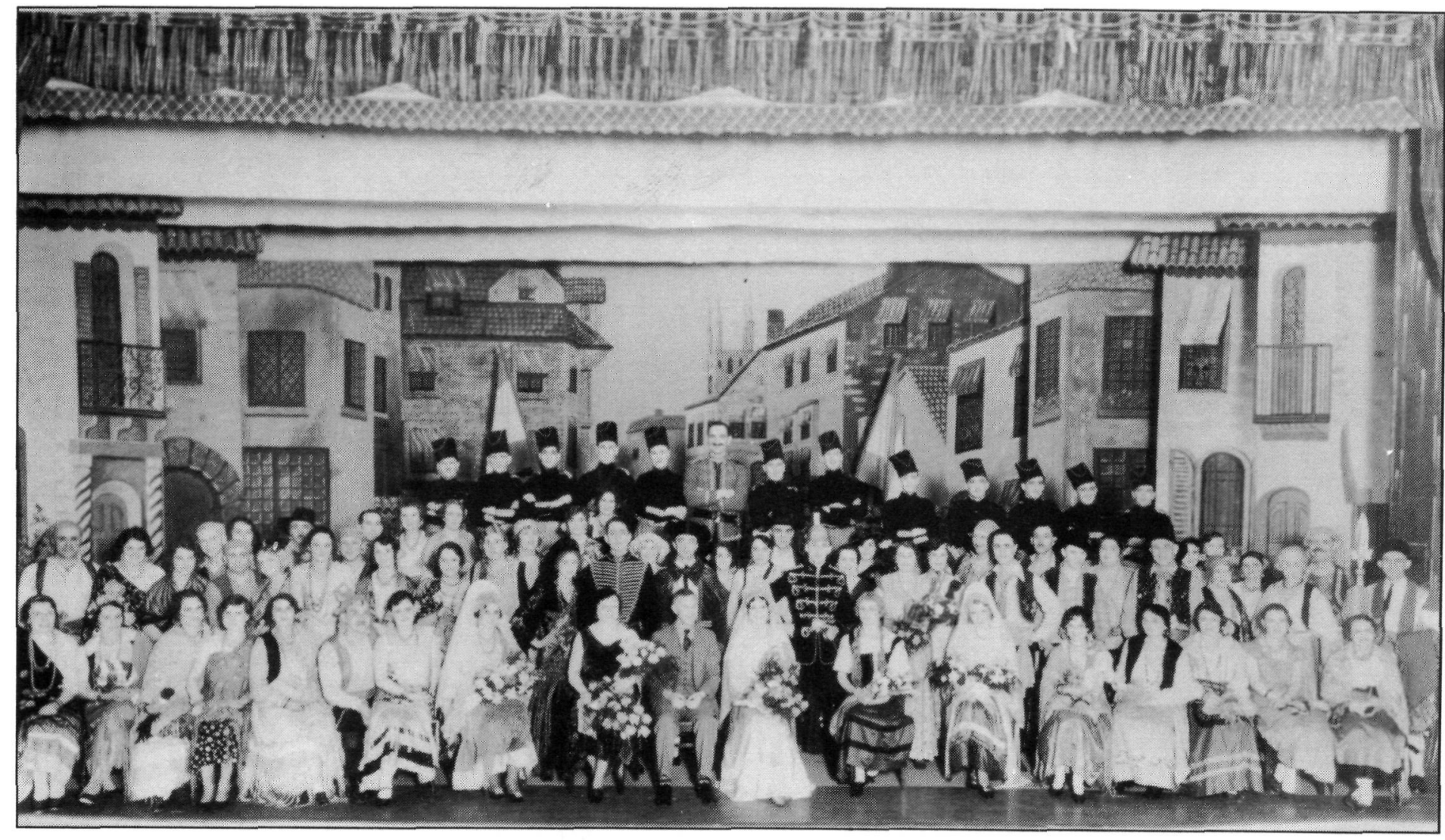

Plate 2: The Edmonton Women's Musical Club production of Carmen 1934 
Her work at the University of Alberta and with the Women's Musical Club must have suggested to Carmichael that Edmonton was a city with a musical culture mature enough to support opera on a larger scale, for on 6 January 1935 she invited a group of friends to her home to discuss the formation of an opera company. ${ }^{23}$ Incorporation of the Edmonton Civic Opera Society was achieved in May of the same year, with the following objectives:

(1) To promote a wider appreciation of the finer classical music and to train promising young musicians to greater achievements in their chosen field of endeavour.

(2) To present high class productions at a minimum cost to our patrons through the co-operative efforts of amateur talent.

(3) To put forth every effort to give the people of Edmonton and district the finest in talent, staging and costume.

(4) To award young vocalists of outstanding ability scholarships that will enable them to continue their studies in the greater centres of art. ${ }^{24}$

As in most Canadian cities, especially those in Western Canada, opera has had a relatively short history. Opera companies require large numbers of competent singers and instrumentalists, an appropriate hall, sufficient funding for costumes and sets, and an audience with the education and financial means to be able to enjoy and support them. Although this might lead one to conclude that they would be among the last musical organizations to appear in a frontier society, this was not necessarily the case. The garrison town of Halifax experienced a number of operatic productions in the last decade of the eighteenth century, only a few decades after its founding in $1749 .{ }^{25}$ In the West, the history of local opera productions varied from city to city. Regular operatic productions by the Victoria Operatic Society began as early as 1885 and continued until 1908. ${ }^{26}$ Colonel J.S. Dennis and Mrs. W. Roland Winter were central to the formation and continued existence of the Calgary Operatic Society, which was established before the turn of the century and continued until 1920.27 There were also a number of touring light and grand opera companies like the San Carlo Opera Company of New York that found it profitable to visit cities from Montreal to Victoria throughout the early decades of this century.

In Edmonton, the advent of the Edmonton Operatic and Dramatic Society in 1904 under Vernon Barford's leadership marked the beginning of more than a decade of continuous productions, specializing, as did so many other similar groups, in the presentation of Gilbert and Sullivan operettas. ${ }^{28}$ Until 1920 Barford, W.J. Hendra (violist, tenor, voice teacher at Alberta College and

23 Edmonton Bulletin, 15 January 1935.

2410 th Anniversary Program.

25Frederick Hall, "Musical Life in Eighteenth-Century Halifax," Canadian University Music Review, no. 4 (1983): 278-307.

$26 E M C$, s.v. "Victoria".

27 EMC, s.v. "Calgary."

28Berg, "Music in Edmonton 1885-1905," 155-56; Berg and Bayley, "W.J. Hendra," 2. 
conductor of the Edmonton Male Chorus from 1917 until 1941), and Howard Stutchbury (a baritone and church musician who later became successful in the petroleum industry) were the primary organizers of operatic productions in the city. No one had attempted to maintain a permanent opera company since Vernon Barford's company had ceased to exist, however, and it remained for Mrs. Carmichael to take the initiative.

The new society lost no time in trying to meet its objectives. Maritana, the first production, took place in April 1935 in the 1,500-seat Empire Theatre with a cast of twelve principals, thirty-eight chorus members, and an orchestra of thirty members. ${ }^{29}$ The show had its problems according to the reviewer, including long scene changes and sluggish stage action. Although the event lost money, Carmichael covered the expenses, later stating that she had "faith in both the company and the singers and acting talent of the city performers." 30

The Society had initially hoped to stage two works each year, one light and one grand opera. Accordingly, in November 1936 Edmonton saw a lavish production of Verdi's Il trovatore. ${ }^{31}$ One aspect of the Society's presentations that critics almost always commented on was the meticulous attention to detail in sets and costumes, even at a time when the economy had still not fully recovered from the effects of the Depression. In 1937 the Society was able to stage two operas in one year: The Red Mill in April and Faust in November. Ruth Carse, who would make a career in New York and Toronto as a dancer before returning to Edmonton to found the Alberta Ballet Company and ballet school, danced in The Red Mill. Noreen Bristow, who developed a professional career as a singer outside of Edmonton while still returning regularly to perform in the Society's productions over the next few decades, sang the lead role in Faust.

Over the next several years the audience for the presentations of the Society grew to the point where they were able to extend their runs to three and then four evening performances plus a matinee. In 1940, for example, Blossom Time in March and Carmen in November both received five performances to full houses. World War II was at the forefront of everyone's minds by this time and the Society donated $\$ 1,000$ of the proceeds from the production of Carmen to the Canadian Red Cross Ambulance Fund.

In 1941 the Society decided to forego the production of a grand opera in favour of a second operetta: Naughty Marietta in March and The Chocolate Soldier in November. The reasons were undoubtedly at least partly practical - grand opera was more expensive and took longer to prepare - but there may have been other reasons as well. Mrs. Carmichael had this explanation, "A light opera takes three months to produce, and grand opera takes six months to produce ... and the public prefers lighter music." 32 Two things are worth

29Edmonton Bulletin, 27 April 1935. Although the first work they performed was a relatively obscure operetta by William Wallace, subsequent productions were mainly drawn from the standard opera, operetta, and musical theatre repertoire.

30 Edmonton Journal, 13 March 1964.

31 Edmonton Bulletin, 14 November 1936.

32 Edmonton Journal, 25 January 1960. 


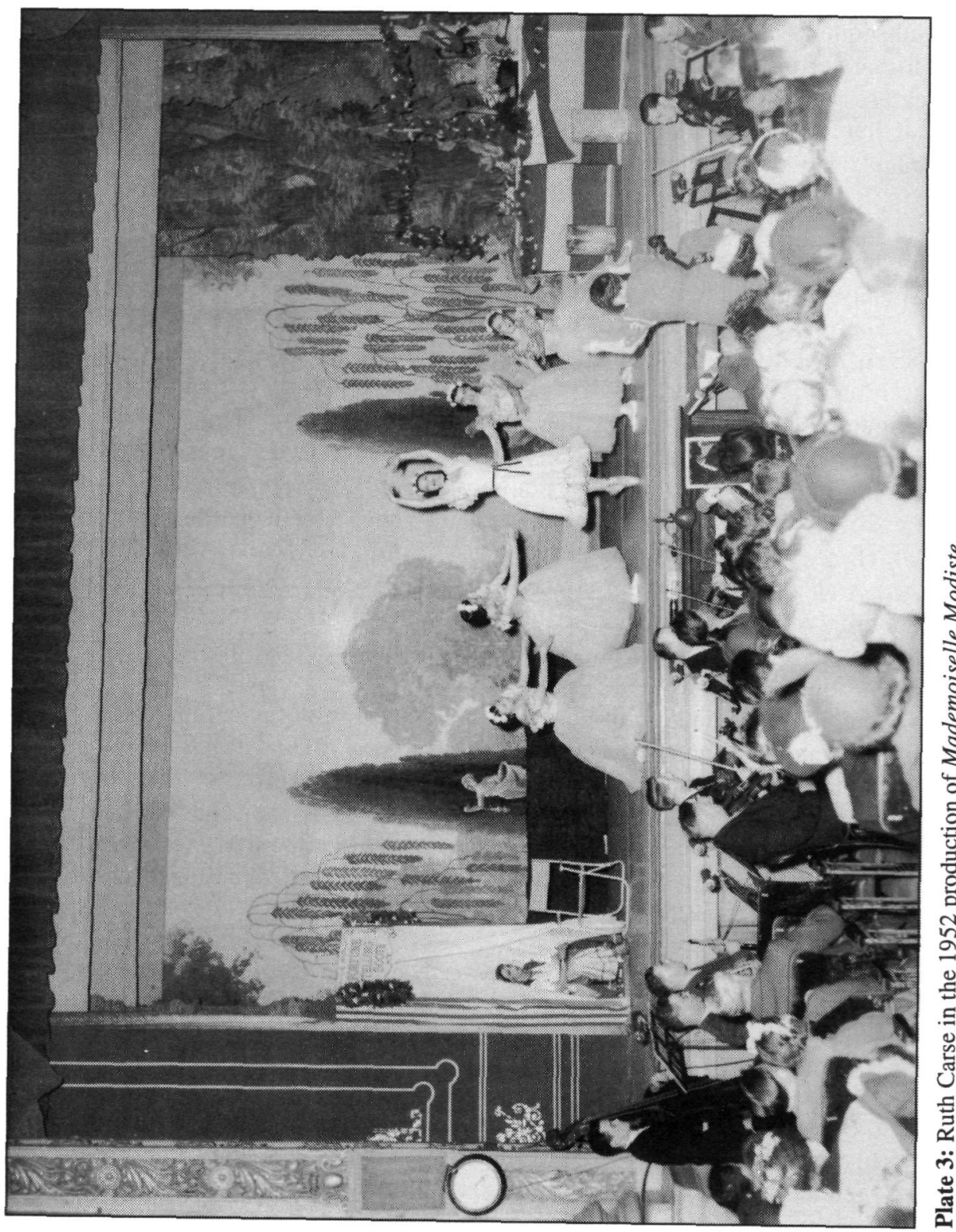

noting about the 1941 productions: Noreen Bristow returned from Chicago, where she had become a member of the Chicago Civic Opera Company, to sing in Naughty Marietta, and the Society gave the Queen's Canadian Fund for British Air Raid Victims $\$ 1,000$ from the proceeds of The Chocolate Soldier, continuing its support of the war effort that had begun the previous year. ${ }^{33}$ In 
subsequent years various charitable organizations received assistance, but the primary effort was directed at providing money and goods such as steam presses, games, magazine subscriptions, and shaving equipment to the men of the HMCS Stettler. ${ }^{34}$ At the end of the November 1947 performance of Rose Marie, Commander Rodney Pike of the HMCS Nonesuch presented Mrs. Carmichael and the Society with a plaque and the ship's bell from the HMCS Stettler in appreciation for their support for the crew during the war. ${ }^{35}$ The sacrifices the Society had made went far beyond the financial: over the six years of the war, sixty-four Society members enlisted and three were killed in action.

There were other ways in which the war affected the Society. By 1942 the shortage of materials and men meant that sets could no longer be quite so lavish and the chorus and orchestra had to be reduced in size. The shortage of male singers was a phenomenon that affected all operatic and choral groups, of course, and considerable ingenuity had to be exercised if music-making was to continue. The other more particular result of the war occurred in 1943 when the Society was displaced from the Empire Theatre by the United States Army, which needed office space during the construction of the Alaska Highway. Although there was some concern that the Society might have to suspend operations until the project had been completed, it was able to negotiate the use of the Strand Theatre during the week - it was in use on weekends - and the productions continued. 36

The war even had its influence on the repertoire of the company. Although it may now seem somewhat strange to survivors of the Cold War, the Society presented Rudolf Friml's comic opera, Katinka, in April 1944 as a tribute to the Soviet Union, then still an ally. Noreen Bristow sang the lead role, after which she left for Vancouver to join Theatre Under the Stars. ${ }^{37}$

The historian J.B. MacGregor has assessed the state of cultural activities in Edmonton during World War II in this way:

Though various indigenous cultural activities had hung through the long depression and had been throttled back during the war years, nevertheless, due to the untiring efforts of individuals who could not be repressed, the cultural pot was kept simmering. Mrs. J.B. Carmichael had kept herEdmonton Civic Opera Society alive and interesting. ${ }^{38}$

Just how crucial Mrs. Carmichael was to the operation of the Society can be seen in the season of 1945 , when she became seriously ill and rehearsals for Rose Marie had to be suspended. That year there was no production for the first time in a decade.

34 10th Anniversary Program.

35 Edmonton Bulletin, 26 November 1947.

36 Constructed in 1913, the Strand was originally known as the Pantages, Edmonton home to the Pantages vaudeville circuit. It was renamed and converted to a cinema in 1931, but was still occasionally used for live theatre. It was eventually dismantled in the building boom of the 1970s. John Orrell, Fallen Empires: Lost Theatres of Edmonton, 1881-1914 (Edmonton: NeWest Press, 1981), 107-17, 131-32.

37 Edmonton Journal, 19 April 1944.

38J.G. MacGregor, Edmonton: A History, 2nd ed. (Edmonton: Hurtig Publishers, 1975), 269. 


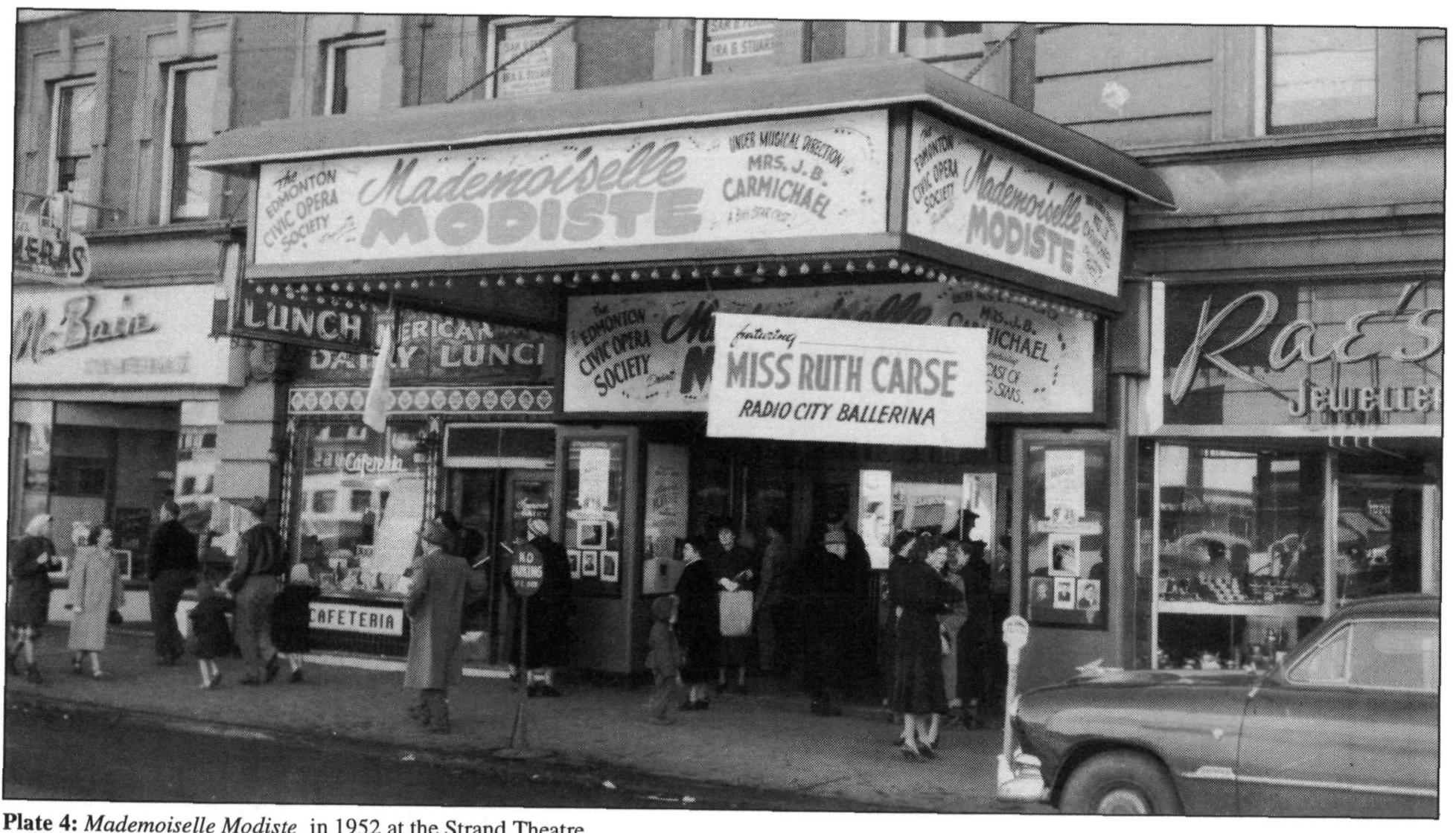

$\stackrel{ }{\stackrel{N}{*}}$

Plate 4: Mademoiselle Modiste in 1952 at the Strand Theatre. 


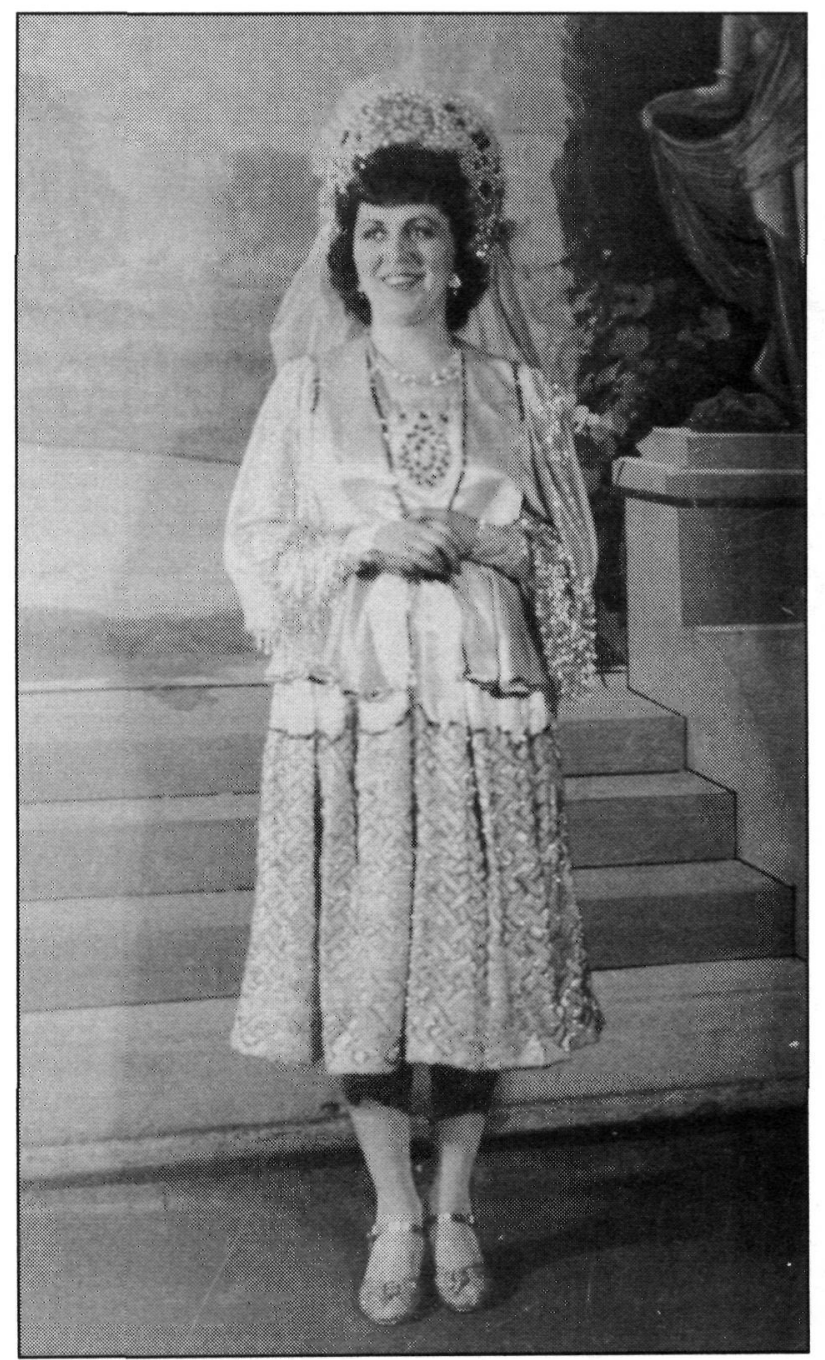

Plate 5: Noreen Bristow as Katinka.

Having survived the difficulties of the Great Depression and World War II, the Edmonton Civic Opera Society seemed poised to enjoy the fruits of a post-war boom fuelled by new-found oil revenues and an influx of European immigrants for whom opera was a necessary and habitual part of life. But there were new challenges as well. The increase in financial and human resources led to a rapid increase in the number of artistic organizations in the late 1940s and early 1950s: The Edmonton Community Theatre (1946), the Edmonton Light Opera Company (1950), the Children's Theatre Group (1951), the Edmonton Symphony Orchestra (1952), Studio Theatre (1952), the Civil Service Playhouse (1952), Mercury Players, Circle 8 French Theatre, the Orion 
Theatre, the Edmonton Chamber Music Society (1952), and the Edmonton Ballet Company (1954). The result was greater competition for audiences and funding, as well as changes in the expectations and critical capacities of Edmonton audiences.

The most significant challenge came in 1954, when Peter Dezman, Vice President of the Society, proposed that the Society return to its objective of performing one light opera and one grand opera each year. ${ }^{39}$ Recognizing that Mrs. Carmichael was now sixty-five years old, he suggested that she could continue to be responsible for the light opera while Jean Létourneau, a native of Quebec City and a tenor who had most recently performed at Radio City Music Hall in New York from 1948 to 1951, would become the assistant musical director in charge of the grand opera. Carmichael would have nothing to do with the proposal and asked the directors to turn it down. With the defeat of the proposal, Mr. Dezman left the Society and with Létourneau formed the Capital City Choral Society in 1955 , later to become the Alberta Opera Society (1958), the Edmonton Professional Opera Association in 1963, and finally the Edmonton Opera Association in 1966.

For the moment, at least, the Civic Opera Society remained the most significant and substantial operatic society in Edmonton, with the main competition coming from Eileen Turner's Edmonton Light Opera Company. In the next few years the Society produced The Great Waltz (October 1955), The Gypsy Baron (April 1956), and Carousel (November 1956), each one with audiences filling the hall to capacity. The year 1957 saw the opening of the Jubilee Auditorium in Edmonton, in celebration of the fiftieth anniversary of the Province of Alberta. The Edmonton Civic Opera Society was asked to perform on opera night during the week of dedication and chose to give a performance of the opera Carmen. Backdrops were flown in from Hungary and Noreen Bristow played Carmen in a lavish production underwritten by the Government of Alberta. ${ }^{40}$

The twenty-fifth anniversary of the Society was celebrated in February 1960 with a production of Guys and Dolls co-sponsored by the Council of Jewish Women and directed by Joseph Shocter, an Edmonton lawyer and founder of the Citadel Theatre. The January 1961 production of Show Boat was one of the Society's most ambitious undertakings, with some eighty people in the cast. The attendance at the opening performance of Kismet in January 1962 was disappointing - just 800 people - an omen of difficulties to come. The next production, The Music Man in November 1962, was the last one that Carmichael was able to conduct. Joseph Shocter was once more the stage director.

The November 1963 production of Can Can was well-attended, with 2,500 people in the audience on opening night, but Mrs. Carmichael had been forced to turn the musical direction over to Herb Jeffrey because her health was beginning to fail. Less than a year later, on 13 March 13 1964, the Edmonton Journal announced that "The grand Dame of Edmonton Opera is Dead." She

39Interview with Peter Dezman, 14 April 1993.

40Edmonton Journal, 4 May 1957. 
had died two days earlier at the age of seventy-five, on 11 March 1964, at her home at 10012-106 Street.

The Society continued to function, with a successful production of The Most Happy Fella in October 1964 under Herb Jeffrey, and a musical review featuring numbers from eighteen of its last thirty-five productions as a tribute to its late founder and musical director on 31 May 1965. The next two shows, Carousel in April 1966 and Call Me Madam in April 1967, received only lukewarm reviews and were seen by small audiences. Clearly, the Society needed to do something to rejuvenate itself. On 22 September 1967, a full-page advertisement appeared in the Edmonton Journal announcing that the Edmonton Civic Opera Society, which had not produced a grand opera since the Carmen of 1957, was changing its name to the Civic Musical Theatre in order to reflect its repertoire more accurately. The Board of Directors also decided to move from the cavernous Jubilee Auditorium to the more intimate theatre in the Student Union Building on the campus of the University of Alberta.

The first production in SUB Theatre was Funny Girl, which ran for five nights in November 1967 to good reviews. In 1968 the Civic Musical Theatre staged three musicals. It may have been trying to do too much in too short a time, or the absence of its founder and artistic spark plug may have begun to take its toll. The productions of 1968 were not well-received by either critics or audiences. The last production of the Civic Musical Theatre in March 1969 was not without a certain irony; it was How to Succeed in Business Without Really Trying. Reviews were good, but attendance was only 500 at opening night. The newspaper announced that if ticket sales did not improve, the Society would be forced to fold, and on 17 May 1971 the Civic Musical Theatre ceased operations. ${ }^{41}$

There can be no question that the first two objectives originally set out by the Society - "to present high class productions at a minimum cost to our patrons through the co-operative efforts of amateur talent"; and "to put forth every effort to give the people of Edmonton and district the finest in talent, staging and costume" - were largely met during the thirty-six years of the Society's existence. From 1935 until the early 1950s the Society was the only stable, continuing organization in Edmonton devoted to the production of classical music, and Mrs. Carmichael's formidable training and determined personality ensured a consistent level of artistic competence. She was able to attract very competent assistants; even her backstage crews remained stable over many years. ${ }^{42}$ The Society also formed smaller ensembles to perform at various functions in the city; in the spring of 1959 such groups gave concerts in outlying communities in Alberta like Olds, Wetaskiwin, and Hinton.

Less was made of the other two objectives: "to promote a wider appreciation of the finer classical music and to train promising young musicians to greater achievements in their chosen field of endeavour"; and "to award young vocalists of outstanding ability scholarships that will enable them to continue their

41 Registry of the Society, Edmonton City Archives.

42 Interview with Lucille and Armand Baril, 2 September 1994. 
studies in the greater centres of art." Conversations with former Society members reveal that Mrs. Carmichael was an unending source of support and encouragement to young musicians in Edmonton. Both Lucille and Armand Baril were given scholarships to leave Edmonton for further musical studies, as were young musicians like Dorothy Blackwell, Noreen Bristow, Harlan Green, and Hilda Thompson.

Noreen Bristow was a student of Mrs. Carmichael who displayed a great deal of potential. She went to the Chicago Conservatory of Music in Chicago and was accepted into the chorus of the Chicago Civic Opera Company. Just when she was beginning to get small parts in productions she was forced to return to Edmonton in 1941 by a war-time decree of the United States government. Although she spent some time with the Vancouver Theatre Under the Stars and continued to perform with the Civic Opera Society for many years, she was unable to pursue the career that had seemed to be opening up for her. ${ }^{43}$ Roxolana Roslak was another particularly talented student of Mrs. Carmichael. She studied with Carmichael as a child and became a member of the Society for several years before leaving for further studies in Toronto and the beginning of a professional career.

Mrs. Carmichael continued to teach voice and piano until late in her life, and students like Mary . O'Donnell Berg remember her as a kind and very competent teacher. ${ }^{44}$ Lucille Baril remembers a distinguished, stylish woman who did everything with elegance and grace: a bottle of perfume always on the piano, a drawer full of white leather gloves in a dresser in the entrance of her house, and a house overflowing with a miniature elephant collection. Conversations with her former students also reveal an image of a woman exuding musicality and aware of international standards of performance and production. For many years she made regular trips to Chicago in the summer to visit her parents, but also to maintain contact with musical developments and to check up on students who had gone to study on Society scholarships. This, when combined with charm, enthusiasm, determination, and a thorough training in voice, violin, and conducting, helps to explain why she was able to accomplish so much and perhaps why the Society fell on hard times when she died. Joseph Shocter, who directed two of the Society's productions, Guys and Dolls in 1960 and The Music Man in 1962, suggests that the two of them got along very well because they were alike in at least two ways: they knew exactly what they wanted and they were both relentless in pursuing those results. The word he used was "indefatigable." 45

Vinyl recordings of several productions - The Student Prince (1951), Show Boat (1961), and The Music Man (1962) - are available in Mr. Peets's collection. Although the surfaces are quite badly damaged, it is possible to get a sense of how the performances in the 1950s and 1960s sounded. Most of the soloists are very good and the overall impression is of engaging, musical

43 Interview with Edith and James Bristow, 7 January 1995.

44 Interview with Mary O’Donnell Berg, April 1993.

45 Interview with Joseph Shocter, 12 September 1994. 


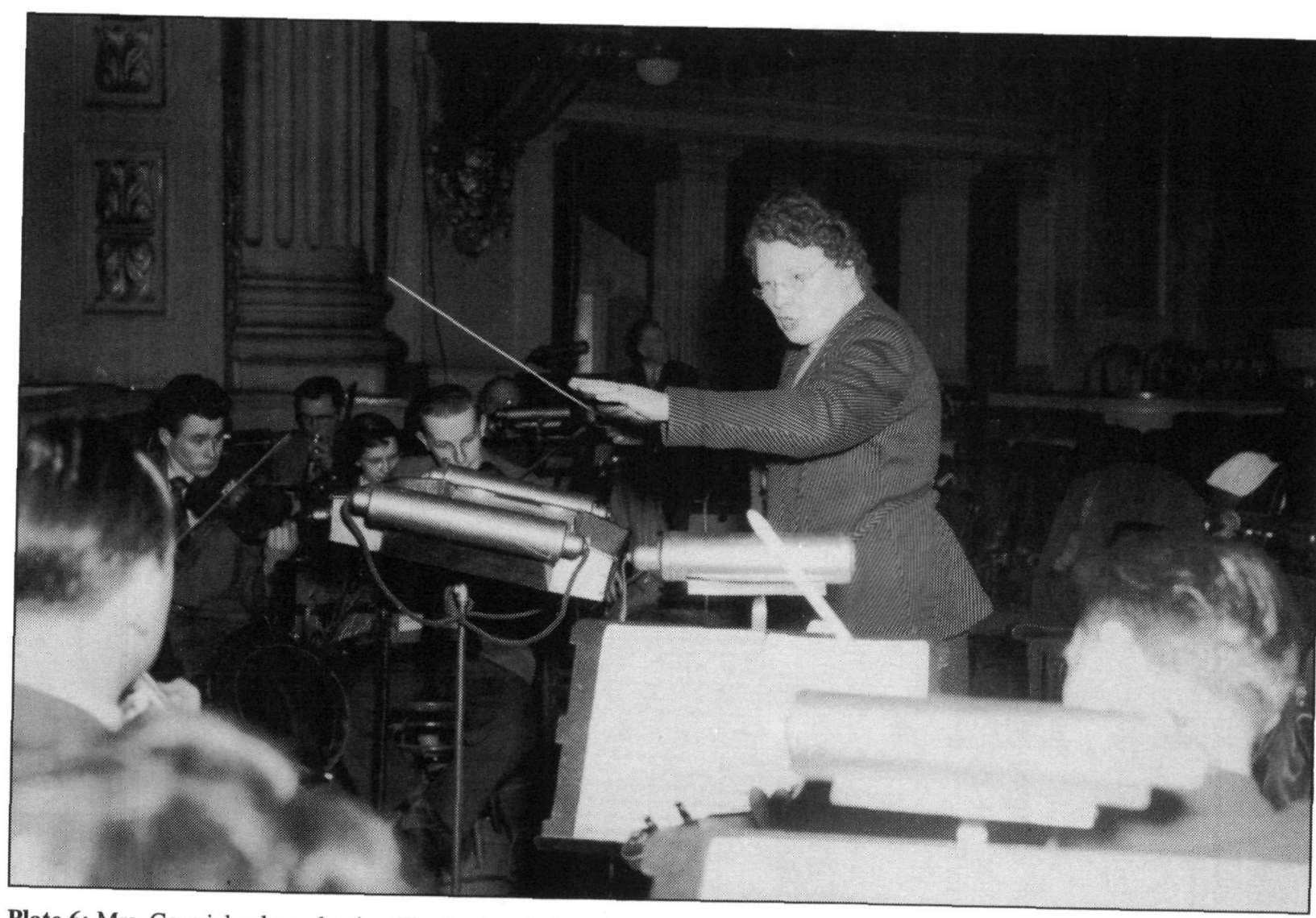

Plate 6: Mrs. Carmichael conducting The Student Prince, 1951. 
performances. This is particularly true of The Music Man, in which both the stage business and the singing and playing are obviously energetic and enthusiastic.

The Edmonton Civic Opera Society was one of many such societies that were formed in cities across Canada to entertain and edify by producing operas and operettas. Similar groups devoted to operetta had become established in other Canadian cities, including Montreal and Toronto in the 1920s and $1930 \mathrm{~s} .{ }^{46}$ Even though many of them lived finite lives, they were an important part of a process that led in the middle of the century to the formation of professional opera companies in most of the major cities in Canada. It would be a mistake, however, to suggest that their importance was limited to preparing the ground for professional organizations.

Ruth Finnegan has pointed out the pervasiveness and importance of local music, not just as the grass roots environment from which the professional symphony orchestras, opera companies, and string quartets that have been the focus of musicological enquiry and interest have emerged, but also as an activity that has validity and worth in its own right. ${ }^{47}$ Participation in amateur musical organizations generates significant amounts of economic activity in addition to providing more intangible benefits in the form of social, aesthetic, and spiritual experiences that enhance the lives of participants and audiences in many subtle yet important ways. ${ }^{48}$ Interviews and conversations with participants in the musical life of a small English city suggested to her that "their music-making was one of the habitual routes by which they identified themselves as worthwhile members of society and which they regarded as of somehow deep-seated importance to them as human beings." 49

Very few members of the Edmonton Civic Opera Society made their living from music: one person we interviewed was an accountant for Greyhound Bus Lines, another worked for Alberta Government Telephones, another was a traffic manager for Gainers, a large local meat packing company. One member of the cast of The Music Man (1962) was Steve Paproski, who was well known as a member of the Edmonton Eskimos of the Canadian Football League and later as a Member of Parliament in Ottawa. Yet every person had vivid memories of Society membership and it was clear that it had played an important and sometimes decisive role in their lives. The mention of names of other members evoked fond memories and reminiscences. Conversations with people who attended the performances reveal that their lives had also been touched and enriched by the existence of the Society. Those singers and musicians whom the Edmonton Civic Opera Society sent away on scholarships because they had the potential to make careers as musicians returned with insights gained from life in major musical centres. They might not come back to sing with the Society, preferring instead to participate in grand opera

46EMC, s.v. "Montreal," "Toronto."

47Ruth Finnegan, The Hidden Musicians: Music-making in an English Town (Cambridge: Cambridge University Press, 1989).

48Finnegan, The Hidden Musicians, 327-41.

49 Ibid., 306. 
productions when possible, but the Society and its vivacious director had left an indelible mark on them and the musical life of the city.

\begin{abstract}
Born in Indiana and trained as a singer, violinist, and conductor in Chicago and New York, Beatrice van Loon travelled to Edmonton, Alberta, in the fall of 1920 as the leader of an all-female ensemble. She married a local dentist and as Mrs. J.B. Carmichael played in the Edmonton Symphony Orchestra and conducted an orchestra at the University of Alberta until 1934. She founded the Edmonton Civic Opera Society in 1935 and worked as its artistic director until her death in 1964. For more than four decades she gave unstintingly of herself to audiences and music students in her adopted city.
\end{abstract}

